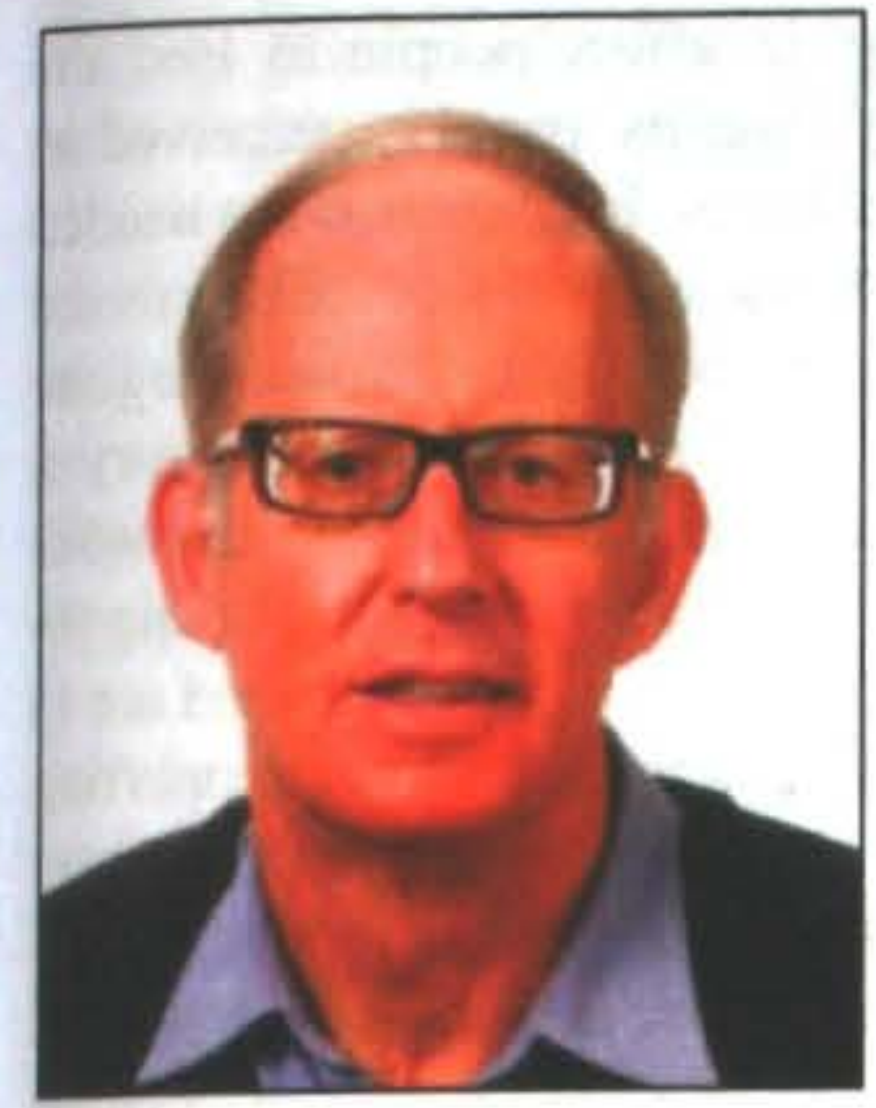

\title{
DAIRY EXPORTING AND EMPLOYMENT: A POSSIBLE ROLE FOR ONCE A DAY (OAD) MILKING
}

\author{
Rupert Tipples
}

\author{
Agriculture and Life Sciences Division \\ Lincoln University
}

\section{Abstract}

The dairy industry is New Zealand's top export earner and recently went through a growth period under the influence of rapidly rising world prices for milk products. They peaked in 2008. Employment conditions in this major sector of the economy have been problematic since the early twentieth century as the prevailing industry mentality is one of cost saving, particularly of labour. Once-a-Day (OAD) milking appeared to provide the key system change which held the possibility of dairy farming becoming socially sustainable rather that lurching from one employment crisis to the next. However, while the changes brought about by conversion to OAD milking are very positive, they have not affected dairy farm employment in some of the ways which were anticipated. The paper reports findings of an in-depth qualitative study of social aspects of OAD milking and their implications, set in the context of data from the 2006 Census of Population.

\section{Introduction - The importance of the dairy industry in New Zealand}

Today agriculture overall is New Zealand's largest export earner. In the year to 30 September 2007 dairy exports alone were $20.7 \%$ of total merchandise export value (NZ Debt Management Office, 2008). These were produced by 3.9 million cows in 11,630 herds (LIC, 2006-2007). Dairy export value in 2008 to 31 March was \$NZ 10.48 billion, which is projected to increase to \$NZ 11.89 billion in 2012 as a result of higher volumes and prices (MAF, 2008).

Most milk is consumed in the country of production. Only 5 percent of New Zealand milk is consumed in New Zealand, with the remainder exported as various milk products. Some 97 percent of New Zealand milk is processed by Fonterra, the farmers' dairy cooperative company. Fonterra is also New Zealand's largest company employing some 17,400 staff worldwide and it is the sixth largest international dairy company. However, it only handles some 3 percent of world dairy production sourced from New Zealand (Fonterra, 2007).

The medium term prospects for dairy production are considered to be good at present although world prices have fallen from all time high levels at the beginning of

2008 (Rabobank, 2008). The European Union has been able to export dairy products without the need for export subsidies for the very first time since its creation fifty years ago. However, future prospects, while looking good, are still quite uncertain if the production potential of a number of large countries (e.g. China, USA, Russia and those of Eastern Europe) is focused on milk production (Woodford, 2007; MAF, 2008). Sustaining
New Zealand milk production and productivity therefore has vital importance for the overall state of the economy.

\section{Social sustainability of dairy farming}

The New Zealand dairy farming industry has a vision of being 'World's best in dairying' and its purpose is: "To enhance the sustainable competitive advantage of New Zealand dairy farming". Sustainability is expressed in an imperative to: "Increase the efficient use of resources, reduce reliance on non-renewable resources, and minimise negative impacts on the environment". Social sustainability is not mentioned expressly but it appears by implication in another imperative: "Be an attractive career prospect for current and potential farmers" (Dairy InSight, 2004). However, whether the industry will continue to be socially sustainable is an open question. As an area of traditional family business it is disturbing to find that while overall only 30 percent of family businesses survive to a second generation, some studies report succession rates as low as six percent for dairy farming (Lockhart \& Reid, 2005) - perhaps an indication of an increasingly unacceptable lifestyle in the age of 'Generation Y' (Lee, 2007). Poor succession rates are probably not helped by the long term negativity of the dairy farming industry towards employees and any attempt to develop them.

The history of the industry supports this view. Dairy farming has been a significant New Zealand economic activity since the introduction of refrigerated shipping in the $1880 \mathrm{~s}$. That permitted the export of butter and cheese, which subsequently became major exports. For many years dairy farming was primarily a family enterprise with little or no employed labour. That is still the dominant form of dairy farming in the North Island. 
Dairy farmers were opposed to organised labour, especially trade unions, because they interfered with the export of their primary produce. This came to a head under the Reform party Prime Minister, William Massey, a Mangere dairy farmer. In 1913 farmers became temporary policemen, known as Massey's Cossacks, to ensure their produce could get through for shipping for export (McLean, 1990).

In the 1930s under the first Labour government agricultural employment was regulated through the first Agricultural Workers Act, 1936, but dairy farmers only agreed to accept the proposals when the government promised to keep them out of the Industrial Conciliation and Arbitration Act and guaranteed then better prices for their produce. However, farmers were not prepared to improve these conditions in subsequent years (Tipples, 1987). The dominant culture of the industry has been opposed to employment save on the conditions set by the employing dairy farmers. Even the Farm Workers' Association, a farm workers collective formed specifically to keep farm workers out of industrial unionism in the 1970s, was not fully supported by the farming community and eventually was largely killed off by dairy farmers refusing to grant any kind of membership clause to the Association when they were experiencing financial difficulties because farm workers were failing to join (ibid.; Angove, 1994).

Sustained opposition to representative farm worker organizations has left workers without representation in the most recent attempts to address the farm labour crisis, such as the setting up of Human Capability in Agriculture and Horticulture following the Human Resources in Agriculture and Horticulture Workshop held in Rotorua in 2002 (Tipples, 2004). The only organization promoting farming amongst the young has been the Federation of Young Farmers' Clubs, which has run a very successful 'Young Farmer of the Year' Competition (Tipples and Wilson, 2007). However, the question remains, how is the industry to be sustained socially with a workforce that can continue to up skill itself to meet the future challenges of competition and the need to keep improving productivity?

\section{Current Dairy Strategies for Staff}

The Dairy Industry Strategic Framework (2004) suggested it was imperative to attract and develop people to help the industry to reach its production and productivity goals. These aims were subsequently elaborated by a pan-industry group of farmers, consultants and training providers, the Dairy People Capability Review Group. They attempted to identify the key targets for the people capability portfolio over the next ten years. 2007-2017 (Dairy InSight, 2007). They perceived the dairy industry as a "...vibrant, knowledgebased industry that provides a wide range of career options and opportunities to its people" (Dairy InSight, 2007 , p. 2), but one which is facing increased difficulty in attracting such people with the desired competencies and skills. This strategy has a fourfold action focus. First, people are needed to support the continuing need for work on people capability, in effect people to lead the people strategy. Secondly, quality people, perceived as the most important area for future investment, are needed through attracting and retaining what are described as the 'right people'. Retention is to be ensured by making the work environment one that would make the industry a career of choice, or as it is stated "...ensuring the work environment matches the perception we are trying to create..." (ibid., p. 2). Thirdly, the people attracted are to be assisted to achieve their potential through supporting their transition into the industry, transforming them through training, and supporting them through the adoption of technology and the use of rural professionals. Finally, achieving sustainable productivity gains is based on a close connection with research and further adoption of new systems and technology, as well as a strategy for on-going learning, with such changes being systematically measured (ibid.).

However, the dairy industry, in spite of its lofty aspirations, recognizes it is not meeting the expectations of prospective employees. It is not attractive compared to other industries because its hours are long; its staff turnover is high; its accident rate third worst in terms of injuries per person employed, with 25-50 percent of workplace deaths occurring 'on farm'; and staff are commonly required to live on farm, which promotes social isolation (Dairy InSight, 2007, pp.2-3). Recruitment and retention are not helped by a lack of rural support networks either (ibid., and AgITO, 2006). Further those situations are potentially even worse, as the strategy notes, with demand for employees increasing as farms get fewer in number and much larger; productivity in cows per employee is static; and future scenarios across the industry suggest that demand for employed labour will increase by 150 percent. All these points were identified in the earlier work of Tipples, Wilson, Edkins and Sun (2005). However, it appears as though the farming community is in denial when Federated Farmers claimed that agriculture offers farm employees "...a competitive rate and a clear opportunity for career development" (Federated Farmers of New Zealand, 2008), but it does not take into account across industry comparisons and the relatively long hours worked in agriculture, especially dairy farming (Rural Network, 2008). On the supply side the key demographic the industry recruits from, Europeans in the 15-39 age group, is declining in number and as a proportion of the population. The growing part of the population is of Maori, Asian and Pacific ethnicity and urban based. Meanwhile competition for labour from other sectors of employment was thought to be likely to increase before the financial crisis of October 2008 (Dairy InSight, 2007; Tipples et al., 2005). With the likely onset of an economic recession what may happen is unclear, but the demographics are still unfavourable.

\section{The occupational structure of the dairy industry}

The five-yearly Census of Population and Dwellings for 2006, which became available in 2007 in the level of detail necessary to conduct a specific occupational 
analysis, supported these contentions. In 2006 24,795 people were found to be working with a main occupation as dairy farming (Statistics New Zealand, 2007). The number of people employed as dairy farmers/dairy farm workers (Occupation classification 61211) had fallen from 29,976 in 1996 to 26,328 in 2001 to 24,792 in 2006 (Tipples, Wilson, Edkins, \& Sun, 2005; Wilson \& Tipples, 2008).

With larger, more complex farms and herds more staff are needed and therefore greater management skills. Recently the numbers of self-employed dairy farmers has been declining and the number of paid employees has been increasing, as is shown in the following Table 1 which shows the percentages for each status in employment classification in recent census years. People are classified according to whether they are working for themselves or for other people - it is recorded for the main job only (Wilson \& Tipples, 2008). Of note is that the "...large increase in employees is not matched by significantly increasing numbers of employers" (ibid., 2008).
Table 1: Dairy farming population proportions (\%) by Status in Employment (Censuses of Population 1991, 1996, 2001, 2006)

\begin{tabular}{l|cccc}
\hline $\begin{array}{l}\text { Status (\% of status } \\
\text { group) }\end{array}$ & 1991 & 1996 & 2001 & $\mathbf{2 0 0 6}$ \\
\hline Paid employee & 18 & 21 & 24 & 37 \\
Employer & 25 & 26 & 32 & 29 \\
Self-employed and & 52 & 41 & 38 & 27 \\
without employees & & & & \\
Unpaid family worker & 4 & 10 & 5 & 6 \\
Not stated & 1 & 2 & 1 & 1 \\
\hline Total & 100 & 100 & 100 & 100 \\
\hline
\end{tabular}

There has also been a profound ageing of the dairy farming population, with the relative share of the population aged less than 35-39 decreasing and that aged more than 45 increasing. Over the 25 -year period since 1991, the biggest change has been an increase in the 1519 year age group (from $4 \%$ in 1991 to $7.9 \%$ in 2006) and a decrease in the 25-29 year and 30-34 year age groups (from $13.5 \%$ and $16.9 \%$ to $9.4 \%$ and $12 \%$ respectively)" (ibid., pp. 8-11).

\section{Figure 1: Hours Worked in Main Job}

\section{Hours Worked by Status in Employment 2006}

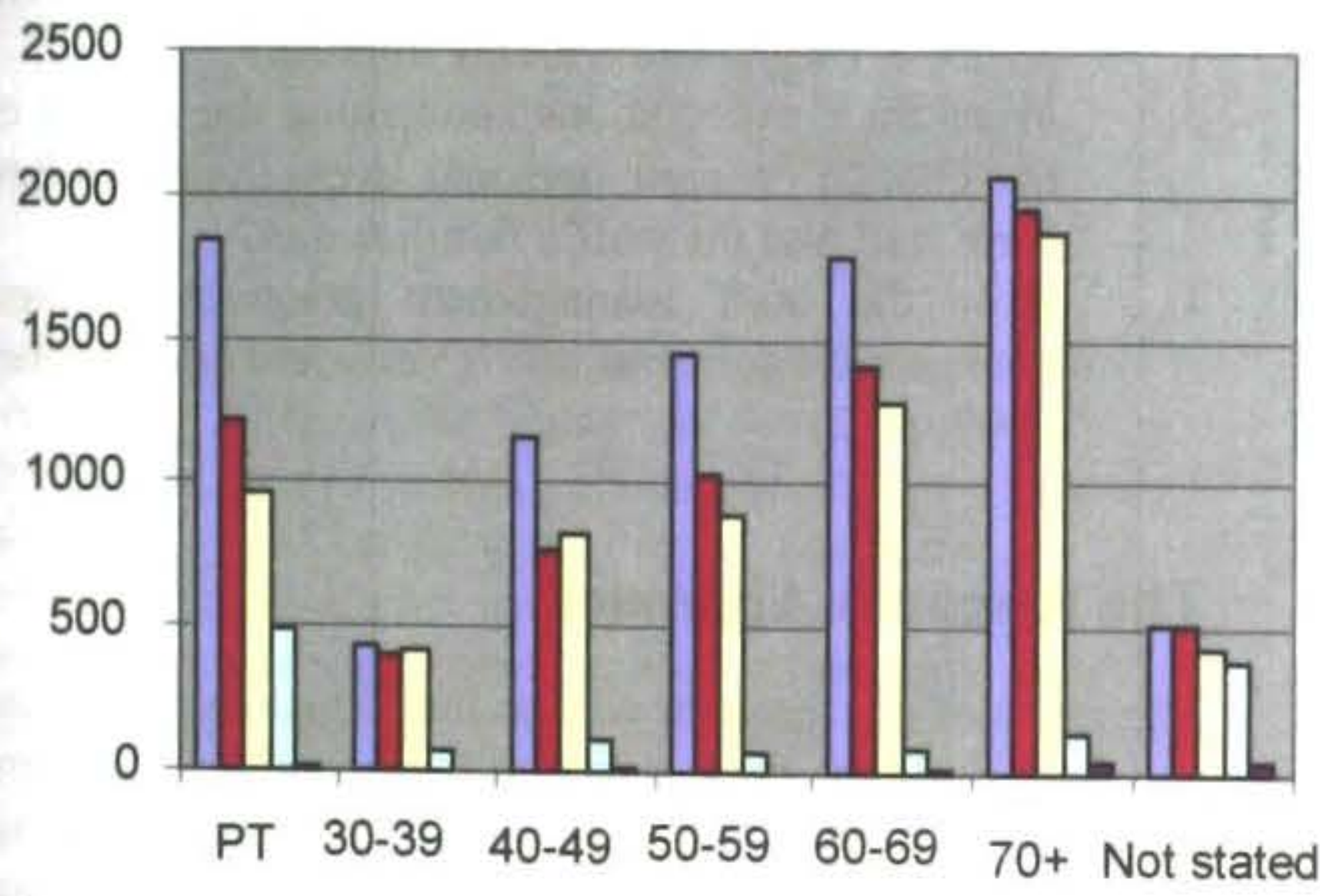

\section{口Paid Employee \\ Employer \\ $\square$ Self-Employed and without Employees}

$\square$ Unpaid Family Worker

Not Stated

\section{Hours of work}

Long hours are nothing new in dairy farming. Doig (1940) reported dairy farmers as working very long hours in 1937-1938, with 65 percent working 65-84 hours per week in busy times, an average of 70.0 hours per week, while permanent hired employees averaged 65 . In his sample there was an average of half a permanent employee per farm. At that time mechanisation of milking was already making an impact and only the smallest herds ( $<20$ cows) were still milked by hand.

With the most recent (2006) increase in the proportion of employees, there has only been a slight diminution in the hours worked. The proportion working over 70 hours per week had been increasing over the previous three censuses (1991, 1996 and 2001) to reach 32 percent in 2001, but had fallen to 27 percent by 2006 (Wilson and Tipples, 2008, pp. 18-20) compared to the industrial norm of 40 hours per week (Blackwood, 2007). Figure 1 shows the hours worked according to status in employment. Paid employees have the largest numbers in all the categories of hours worked, probably a direct result of the increase in employees within the dairy farmers/dairy farm workers population as a whole. Those working part-time (PT) and in the three categories of 50+ hours worked were most likely to be employees, followed by employers and then self-employed without employees, which follows the overall percentages in each status in employment category. 


\section{Ways to overcome staffing problems while maintaining productivity}

The dairy farm staffing problems described above have now been apparent since the late 1990s, in greater or lesser degree, depending on the region of New Zealand considered (Tipples, Hoogeveen and Gould, 1999). Personal involvement with research on such workforce issues goes back to that study and to a Ministry of Agriculture and Forestry research contract in 2000 (Morriss, Tipples, Townshend, Mackay and Greenwood, 2001). They led to a project for Dairy InSight to investigate future dairy farm employment (Tipples, Wilson and Edkins, 2004). That study was based around the Human Capability Framework and involved considering all influences on future supply and demand factors for dairy farm labour.

One idea which arose at that time was the practice of 'Once-a-Day' (OAD) milking rather than the more usual practice of 'Twice-a-Day' (TAD) milking (Tipples et al., 2004 , pp. 83-84). This appeared to have more potential than the more expensive automatic milking systems, which could also reduce the drudgery of milking TAD. Then a research colleague, Nona Verwoerd, suggested an initial enquiry into the social impact of OAD milking. A small surplus from a previous project permitted this initial study (Tipples and Verwoerd, 2005). The fortuitous presence of another colleague with journalistic leanings at a seminar reporting the initial results led to a press release about what she perceived to be a newsworthy topic. The reaction was immediate when it was published at the end of January 2006. It led to rural radio news interviews in both New Zealand and Gippsland, Victoria; also to other extended print articles; and eventually to an enquiry from Peter Gatley, the General Manager, Genetics, of Livestock Improvement, the New Zealand dairy breeding organization. A publicity campaign about OAD milking had traversed New Zealand in 2004 and 2005 highlighting the positive experiences of adopters and featuring the growing body of research that had become available. By September 2006 the dairy industry was suggesting $\mathrm{OAD}$ milking ws being used by famers for the following reasons: To spend less time milking cows: to reduce staff pressure; to alleviate feed shortages; to improve stock health (lame cows, light cows, heifers, milk-fever prone cows); to aid reproduction (non-cyclers, heifers, or whole herd in a feed shortage): to facilitate using a small dairy shed for the herd size; and to help cope with farm layout problems where they required a long walk to the shed (DairyNZ, 2008).

Our 2005 initial enquiry had given certain valuable insights into OAD milking. On one farm studied while working hours were reduced, wages and staffing levels were left unchanged. Profitability declined initially, but staff turnover fell to zero and accidents and sick days fell dramatically. There was time for training, not just good intentions. Also, with OAD staff worked 'smarter', taking more responsibility and combined tasks well because they were well rested. Further, there was evidence OAD milking opened up new possible sources of labour such as married women with school age children. Further, OAD made a gradual retirement possible for older dairy farmers in a very positive way. Dramatic changes in the work environment were apparent to employees and a better balanced lifestyle, which made OAD work very attractive (Tipples, Verwoerd, Bewsell, Dalley and Turner \& Turner, 2007).

When Peter Gatley made a special visit to see us at Lincoln, we realized he wanted further research carried out on the social effects of OAD milking. He then injected initial seeding money which permitted obtaining further funds from Lincoln University Research Fund and Dairy InSight. In all some \$NZ 86,000 were put into a full study of what became The Human Face of Once-aDay Milking (Verwoerd and Tipples, 2007), which was completed in September 2007.

\section{The Research Questions}

Although our initial study in 2005 had begun to explore why farmers were increasingly adopting $\mathrm{OAD}$ milking, it was only based on six farms in Canterbury, which is not a traditional dairy farming region. So a better grasp of what was happening at national level was required. Our research was conceived on a descriptive level with the following research questions:

1. "What changes happen when a dairy farmer converts from 'Twice-a-Day' (TAD) milking to 'Once-a-Day' milking?

2. Why did the farmers in the study change from Twice-a-Day to Once-a-Day milking?

3. Were their expectations concerning the impact of the change on their personal lives, their families, their staff and the staff's families met?

4. How did staff management practices on-farm change after conversion?" (Verwoerd and Tipples, 2007, p.22)

\section{The Research Approach}

The focus of our research was on individual dairy farmers and their families; their staff and their families, on farms that had converted from TAD milking to OAD milking. Each respondent was approached as a unique individual because they were believed to be able to offer deep understanding into their own personal experiences. Each farm was treated as a case study unit following Y in (1994). The information provided by respondents was taken at face value. Data provided during an interview was probed to ensure its validity as far as possible. Respondents were encouraged to provide their experiences in their own words. Interviews were recorded and notes also taken (Verwoerd and Tipples, 2007, pp.22-23).

One advantage of Livestock Improvement's involvement was that they were able and willing to provide a list of $\mathrm{OAD}$ farmers from their database of all New Zealand dairy farmers. All farmers chosen had previously indicated their willingness to be involved in further research. Of the 67 names provided, 59 were in the North Island and 8 in the South Island. To manage research 
funding responsibly it was decided to interview all 8 in the South Island, but only 6 were available. As many as possible were to be interviewed in Waikato and Northland. Twenty farm case studies were carried out in the end, 6 in the South Island, 6 in Northland and 8 in Waikato. Further interviews were not believed to be likely to add to the explanations received. In effect theoretical saturation (Strauss and Corbin, 1990) had been achieved. Each interview was preceded by an introductory letter and a phone call to arrange a meeting. No previous contact with any of the chosen farms had occurred. In only one case did a prospective interviewee decline to be interviewed. Afterwards respondents were thanked by letter with a promise of a complimentary report. In one case only the interview was rejected when it became clear that the subjects were not involved in OAD milking (Verwoerd and Tipples, 2007, pp.22-23). Data were gathered from interviewing as many people on each case study farm as was possible including farmer and spouse, their adult children and grandparents or other extended family, where available, and available staff members and spouses too:

\begin{abstract}
"The digital recordings turned out to be less useful than the notes. Recording an interview where people come and go, the phone rings, there might be a parrot squawking in the background and rain hammering down on a corrugated iron roof tended to compromise the quality of the recording. Fortunately the interviewer was experienced at taking down interview notes verbatim without losing eye contact or getting lost in the conversation." (Verwoerd and Tipples, 2007, p.25).
\end{abstract}

Research plans had been developed in October to December 2006. After Christmas the research questions developed were tested; ethics committee clearance obtained; and background work concluded. From February, after a pilot study, appointments began to be made and interviews conducted. After each interview notes were written up before going onto the next Interviewing and note making continued throughout the period March to June 2007. July was devoted to data analysis, with the report being written up and completed largely in August. It should be noted that the work schedule was not continuous, but involved periods of frantic activity interspersed with substantial breaks. The project was only ever intended to be part-time, involving some three days per week.

\section{Research Results}

Each case study farm was written up as a separate case study in the final report, taking approximately a page (Verwoerd and Tipples, 2007, Chapter 4, pp.26-45). Taken together the case studies provided an overall picture of $\mathrm{OAD}$ farms. They tended to be of small to average size from $62-363$ hectares (mean $=175$ hectares), with between $120-750$ cows (mean $=336$ cows). Cows were mainly Jersey/Friesian crossbreeds, with 3 Jersey herds, one Friesian and one Shorthorn. This group of farmers were reasonably similar to that revealed by a survey of OAD producers carried out by Livestock Improvement (Gatley, 2007) in which OAD farms ranged from 40-1650 cows, with a mean of 239.

\section{Farm History and Business Structure}

Family associations with particular farms varied widely from the family who had settled one farm in 1919 and were still occupying it, to one only bought three years previously. None of the farms were chosen or designed for $\mathrm{OAD}$, although some changes were being planned for it. All the OAD farmers were owner occupiers and not share tenants, although ownership took different forms with partnerships, companies and family trusts. Such dairy farmers had greater freedom of choice over their production systems.

\section{When did the change to OAD occur?}

Eleven farmers had switched to OAD milking in the last three years, four had changed 4 years ago, two each 5 and 6 years ago and one 7 years ago. Those earliest converters had changed when $\mathrm{OAD}$ had a bad name, with such farmers being regarded as lazy or less than adequate because they could not manage their feed adequately.

\section{Reasons for the change to Once-a-Day milking}

Farmers tended to be driven by three overriding values in their decision making: health of their animals; sustainability, which might be described as balance or fairness; and people welfare. Profitability was always a component in their decision making but not exclusive. These farmers were not totally money driven, but very thoughtful and with a large "...emotional and practical investment into farming practices that were fair and sustainable." Verwoerd and Tipples, 2007, p.47)

Changes might be promoted by a change of thinking, such as:

" '...there's got to be a better way'. Discomfort with animal health, high empty rates, staffing frustrations, and a farming system that was just not running optimally forced a re-think of the entire operation" (Ibid.)

The new thinking was based on experience and knowledge of own stock, reading what was available, talking to farm consultants, and sharing with farm discussion groups. Sometimes farmers had changed to $\mathrm{OAD}$ because of the shape of their farms, where cows had to walk long distances to each milking, or where they had to cross natural or manmade barriers such as a ridge, or main road, or swampy ground. The stress that these obstacles added to both stock and personnel had encouraged the change.

Another incentive for change was the 'burning platform' (Embley, 2005). Impending burnout was the accelerant here, not just hard work. 
"During the season, every day is harvest day and the routine can be unrelenting. When a farmer reaches a point of burnout, meaning that normal, legitimate human needs are neglected to the point of emotional starvation, something has to give." (Ibid., p.47-48).

A change to $\mathrm{OAD}$, while it may have appeared desperate at the time, often provided a way-out, some balance and quality of life. Balance between work, family life, play, and meeting personal needs, was recognised to have been enhanced by OAD milking by the majority. That improvement was most often associated with 'time', which was not totally surprising when it is recalled that the time environment of dairy farm work was the most frequently cited 'critical incident' in previous research to establish dairy farming psychological contracts (Tipples et al., 1999).

\section{Time, Stress and Distress}

More time represented several things:

- $\quad$ "More sleep, feeling more rested and able to work

- Less rush, less stress

- More flexibility when and how to do things equals more logical organisation and method

- Bigger blocks of time available, therefore jobs get completed. This adds up to more job satisfaction, better quality farming, a safer farm environment

- Better quality family life, better relationships

- Opportunity for sport, hobbies, community involvement." (Verwoerd and Tipples, 2007. p.48).

Respondents clearly linked having more time to making better choices. While routines remained remarkably similar, there was now discretionary time. They were more positive because OAD gave them choice and converted work back from drudgery to useful labour. This also put back elements of "...control, spontaneity, and executive thinking into the day" (Verwoerd and Tipples, 2007, p.48). Stress in farmers' lives is often caused by time constraints.

"When stress is interpreted as challenge and there is

a reasonable chance of meeting the challenge, working hard and working smart becomes a pleasurable adult game with high potential rewards. However, when work turns into drudgery and stress into distress emotional and physical fatigue take over and because the rewards just don't measure up to what is demanded." (Verwoerd and Tipples, 2007, p.50).

Every respondent agreed that stress levels went down when OAD milking was introduced.

\section{Staffing Issues}

Stress on dairy farms both affects staff and can be caused by them. While the study was to investigate the effects of OAD milking on staff, only four farmers employed more than one staff member. The dairy farmer with most staff in the study changed to OAD for reasons of staff welfare: "...they wanted to give staff a better working environment, better quality of life, and encourage them to be better parents." (Verwoerd and Tipples, 2007, p. 51)

The most unexpected finding of this study was that most of the dairy farmers studied did not want to be employers at all. Changing to OAD milking made it possible to manage without staff. These farmers farmed for traditional reasons: lifestyle, love of animals, breeding animals, being one's own boss, and raising a family, not because they wanted to be employers. They gave the following reasons:

- $\quad$ "Dislike of having staff live with the family, with resultant lack of family time and privacy

- Specific instances of having been let down by staff at crucial times during the season

- Unacceptable legal requirements regarding employment of staff

A sense of personal inability to be an employer and exercise authority

- $\quad$ Financial reasons, citing significant savings (both obvious and hidden savings) in not having to employ staff

- A sense of freedom and independence, of control regained, by working alone or just with the help of family." (Verwoerd and Tipples, 2007, p. 52)

While a rosy picture of $\mathrm{OAD}$ milking has been painted from the human angle, there were some disadvantages for staff. OAD milking takes more time per milking, which can become more boring. Thus concentration may become problematic. Where farmers do not want to employ staff they are probably limiting their farm growth potential to what the family can manage itself. For workers there may be some problems going back to TAD milking, but with staff so short in the industry that is unlikely to exclude them from future employment. Thus they will still be able to move around on the usual dairy farming annual cycle if they choose (Tipples and Lucock, 2004).

\section{Conclusions: answering the research questions}

The research questions to investigate The Human Face of Once-a-Day Milking were:

1. What changes happen in human terms when a dairy farmer converts from 'Twice-a-day' (TAD) milking to 'Once-a-day' (OAD) milking?

2. Why did the farmers in the study change from Twice-a-Day to Once-a-Day milking?

3. Were their expectations concerning the impact of the change on their personal lives, their families, the staff and the staff's families met?

4. How did staff management practices on-farm change after conversion?

The farmers studied changed "... because they were looking for a better way to farm", which included "... better health for their animals, more sustainable use of the land, more production for less input, and above all, a 
better and more satisfying life for themselves and their families on the land." (Verwoerd and Tipples, 2007, p. 54) Only one farmer out of twenty wasn't sure if OAD milking was an improvement.

\section{Dairy farmers are tired. Not because of hard work, but because of too much pressure.}

$O A D$ offers a way to farm better and longer and even, possibly, to make more money. It offers a way for farming families to survive as families; it adds up to better quality of living. (Verwoerd and Tipples, 2007, p. 54)

Thus from the farmers point of view OAD enhanced the social sustainability of dairy farming. For farm employees, the response from the small number in the study was positive, which reinforced the earlier 2005 data. The change, which was unexpected, was the reduction in the use of employees in favour of family. Managing staff was stressful and only family helpers entailed less formal staff management procedures.

\section{The Future}

The future of $\mathrm{OAD}$ milking for enhancing dairy industry social sustainability is not clear but the signs are very positive. For family farming it has a lot to offer within the scale the family can manage. Whether it will have the same appeal to corporate dairy farming, which appears to be increasing, is unclear. Rakaia Island Dairies' experiences as a family business operating at a corporate scale, suggests that it has great potential for large dairy farming businesses. These possibilities could be encouraged by vigorous selection and breeding for cows with better $\mathrm{OAD}$ milk and milking characteristics (Rakaia Island Dairies, 2008). Perhaps that explains Livestock Improvement's interest in getting this research done!

Most interestingly a recent study has reported increasing the use of farm labour to reduce fatigue and improve efficiency. Another full time worker was employed on a 600 cow sharemilking unit at a cost of $\$ 50,000$ per annum to reduce the hours worked by all staff; to free up the sharemilker's time to spend quality time training staff; to introduce new farming systems; and having the time to do other things and put family first. The study reports many promising indications of a positive outcome for this revolutionary dairy farming business strategy and concludes:

"To introduce more labour into the system you must be able to capture increased productivity so, yourself or someone else on the team must be skilled in the area of staff management. Time must be put into training and the implementation of new and existing systems/science/technology.....

...Increasing the number of staff on dairy farms, compared to current industry standards, is an approach that runs contrary to current thinking as well as demographic and economic trends.
However, if the industry did this the reduced hours and improved conditions means the pool of people available to the industry would become larger as it became more competitive with other industries. It would lead to more people making the Dairy industry their career of choice.

Employers who improved the hours and conditions they provided for their staff would put pressure upon those who didn't, as they are competing for the same staff.

The reduction in hours must be directly linked with increased and improved training. One cannot be properly achieved without the other..." (Kyte, 2008, pp. 1112).

In academic and research terms further exploration of 'time' issues is essential. This might take three different directions. Either dairy farms could be considered as 'greedy organizations', which 'make total claims on their members" and "attempt to encompass the whole personality". They are described as greedy because they demand "exclusive and undivided loyalty" and try to "reduce the claims" of their members. "Their demands on the person are omnivorous" (Coser, 1974). The implications of 'greedy' status for work-life balance for family and employees could then be considered. Or, because the dairy industry is concerned about its future sustainability, increasing the efficient use of its resources and reducing reliance on non-renewable resources, it should start considering its workforces' time as one of its vital non-renewable resources, properly budgeted out on 'opportunity cost' principles (see De Bruin-Judge, 2007; Kyte, 2008), OAD milking certainly impacts that. That might also help explain why statutory compliance is such a concern to dairy farmers and many other small and medium enterprises. Or, finally, there is the issue of time worked and fatigue, and how that might be related to the very high level of farm workplace deaths and other accidents. Again OAD milking appears to have very positive effects on fatigue and related stress levels.

\section{References}

AgITO (2006) Monitoring Project. Focus group research, November, quoted in Dairy InSight (2007) Dairy Industry Strategy for its People and their Capability.

Angove, N. (1994) The New Zealand Farm Workers Association: Its rise and fall 1974-1987. In Pat Walsh (Ed.) Trade unions, work and society - the centenary of the arbitration system. Palmerston North: The Dunmore Press Ltd.

Blackwood, L. (2007). Employment agreements: Bargaining, trends and employment law update. Wellington: Industrial Relations Centre, Victoria University. 
Coser, L. A. (1974) Greedy Institutions: patterns of individual commitment. New York: Free Press. Quoted in Bartram, T., Burchielli, R. and Thanacoody, R. (2007) "Work-Family Balance or Greedy Organizations", AIRAANZ conference, University of Auckland. February.

Dairy InSight (2007) Dairy Industry Strategy for its People and their Capability. Report of the Dairy People Capability Review Group. March.

Dairy NZ (2008) farmfact - 4-1 Once-a-Day Milking Farm setup. Updated September 2006 and downloaded from http://www.dairynz.co.nz/page/pageid/214583678 1/4-0_Once-a-Day_ Milking_(OAD) on 26 November 2008.

De Bruin-Judge, R. Invisible work of partners in compliance for small-business operators. Chapter 13 in Waring, Marilyn and Fouché, Christa (eds.) Managing mayhem - work-life balance in New Zealand. Wellington: Dunmore. pp. 235-253.

Doig, W. T. (1940) A survey of standards of life of dairy farmers. Bulletin No. 75, Social Science Research Bureau, Department of Scientific Research. Government Printer: Wellington.

Embley, K. (2005) The Burning platform. Policy Perspectives, Vol. 1, Issue 1. Downloaded on XXXX from: http://www.imakenews.com/cppa/e_article000368 1179.cfm

Federated Farmers of New Zealand (2008) Farm worker remuneration report released. Media release downloaded from http://www.fedfarm.org.nz/n109,10.html?print=tru e on 25 November 2008.

Fonterra (2007) Fonterra leading the way. Downloaded on 19 October 2007 from: http://www.fonterra.com/wps/wcm/connect/fonterr acom/fonterra.com/our+business

Gatley, P. (2007). OAD Milking: Surveys of Farmer Opinion. Proceedings of The Once-a-Day Milking Conference. Tempero Centre, LIC, Newstead, Hamilton. Monday $16^{\text {th }}$. - Tuesday $17^{\text {th }}$. April. pp. 55-71.

Kyte, R. (2008) A different approach to staffing in the dairy industry. South Island Dairy Event (SIDE), Discussion paper downloaded on 26 November 2008 from http://side.org.nz/index.php?BackStructure $=4 \& \mathrm{La}$ yout=print\&MainLayout=print

Lee, A. (2007) Why do we need Generation Y?, Dairy Exporter, May, p. 66.
LIC (2006-2007) LIC Dairy Statistics 2006-2007. Livestock Improvement Corporation Ltd., Newstead, Hamilton.

MAF (2008) Situation and outlook for New Zealand agriculture and forestry (August 2008). Downloaded on 26 November 2008 from: http://www.maf.govt.nz/rural-nz/statistics-andforecasts/sonzaf/2008/page-19...

McLean, G. (1990) Masters or Servants? A Short History of the New Zealand Merchant Service Guild. N. Z. Merchant Service Guild : Wellington. $96 \mathrm{pp}$.

Morriss, S., Tipples, R., Townshend, W., Mackay, B. and Eastwood, C. (2001) Skill and labour requirement in the Primary Sector -"People make the Difference". Report prepared for the Ministry of Agriculture and Forestry. Massey and Lincoln Universities.

New Zealand Debt Management Office (2008) Composition of Merchandise Exports and Imports. Downloaded from http://www.nzdmo.govt.nz/pubkications/nzefo/200 8/13.htm on 25 November 2008.

Rakaia Island Dairies (2008) Sustainable Farm Practices Once-A-Day Milking, downloaded on 12 November 2008 from: http://www.rakaiaisland.co.nz/index.php?pr=Once _-A_-_Day

Rural Network (2008) Farm bosses get their pound of flesh", downloaded from: http://www.ruralnetwork.co.nz/farm-bosses-gettheir-pound-of-flesh/

Statistics New Zealand (2007) Census of Population and Dwellings 2006. Additional tables provided for The Human Face of Once-a-Day Milking study by Statistics New Zealand.

Strauss, A. and Corbin, J. (1990) Basics of qualitative research. Newberry ParkCA.: Sage Publications Inc.

Tipples, R. (1987) Labour Relations in New Zealand AgriculturE, Sociologia Ruralis, XXVII, 1, 38-54.

Tipples, R. (1995) The re-regulation of farming employment relations in New Zealand. Sociologia Ruralis, XXXV, No.1, 93-109.

Tipples, R. (2004) A solution to too few working down on the farm - The Human Capability in Agriculture and Horticulture Initiative. Proceedings of the Eleventh Labour, Employment and Work in New Zealand 2004 Conference, Victoria University of Wellington, 22-23 November, pp.41-48.

Tipples, R., Maria H. and Eriko G. (1999) Psychological contracts in dairy farming. in 
Tipples, Rupert and Shrewsbury, Helen (1999) Global Trends and local Issues, $7^{\text {th }}$ Annual International Employment Relations Association Conference, Lincoln University, 13-16 July. Held at the Copthorne Hotel, Durham Street, Christchurch. pp. 545-556.

Tipples, R. and Lucock, D. (2004) Migrations and Dairy farming. Primary Industry Management, 7, 1, 33-35, March .

Tipples, R., Wilson, J. and Edkins, R. (2004) Future Dairy Farm Employment. Report prepared for Dairy InSight Research Contract 10015/2003. 116 pp. 2004.

Tipples, R. S., Jude W., Reuben, E. and Xiaomeng, S. (2005) Future Dairy Farm Employment in New Zealand - An Application of the Human Capability Framework. Employment Relations Record, 5, 1, 27-40.

Tipples, R. and Jude W. (2005) The dairy farming population and migrations. Primary Industry Management, 8, 1, 41-43, and 45. March.

Tipples, R. and Verwoed, N. Social impacts of Once-aday Milking on Dairy Farms in New Zealand. Teaching, Learning and Research in Institutions and Regions. Proceedings of the $5^{\text {th }}$ Annual Pacific Employment Relations Association Conference, Yeppoon, Queensland, Australia. 2124 November 2005, pp. 291-302.

Tipples, R., Verwoerd, N., Bewsell, D., Dalley, D., Turner, D. and Dave (2007) Social impacts of Once-a-Day milking. Proceedings of the Once-aDay Milking conference, Tempero Centre, LIC, Newstead, Hamilton. 16-17 April. pp. 23-27.

Tipples, R. and Wilson, J. (2007) Work-sport competition: the role of agricultural contests in New Zealand. Rural Society, 17, 1, 34-49, 2007.

Tipples, R., Verwoerd, N., Bewsell, D., Dalley, D., Turner, D., \& Turner, D. (2007). Social Impacts of OAD Milking. Proceedings of The Once-a-Day Milking Conference. Tempero Centre, LIC, Newstead, Hamilton. Monday $16^{\text {th }}$. - Tuesday $17^{\text {th }}$. April. pp. 23-27.

Wilson, J. and Tipples, R. (2008) Employment Trends in Dairy Farming in New Zealand, 1991- 2006. Agriculture and Life Sciences Division Research Report no. 2, February. Lincoln University, Canterbury, N.Z.

Woodford, K. (2007) Moving Forward in Dairy, an address to the Australia Dairy Business of the Year Conference, Melbourne, 18 May.

Yin, R. K. (1994) Case Study Research, Design and Methods ( $2^{\text {nd }}$. Edition, Vol. 5). London: Sage Publications.

\section{Acknowledgements}

Funded by dairy farmers through Dairy InSight, the Livestock Improvement Corporation, and by Lincoln University Research Fund.

\section{Author}

Rupert Tipples

Senior Lecturer

Agriculture and Life Science Division

Lincoln University

P O Box 84

Lincoln 7647

Canterbury

Rupert.Tipplesr@lincoln.ac.nz 